Federal Reserve Bank of Minneapolis Research Department

\title{
Taxation, Entrepreneurship and Wealth
}

\author{
Marco Cagetti and Mariacristina De Nardi* \\ Working Paper 632
}

June 2004

\begin{abstract}
Entrepreneurship is a key determinant of investment, saving, wealth holdings, and wealth inequality. We study the aggregate and the distributional effects of several tax reforms in a model that recognizes the key role played by the entrepreneurs, and that matches very well the extreme degree of wealth inequality observed in the U.S. data. We find that the effects of tax reforms on output and capital formation can be particularly large when they affect the majority of small and medium-size businesses, which face the most severe financial constraints, rather than a small number of big businesses. We show that the consequences of changes in the estate tax depend heavily on the size of its exemption level. The current effective estate tax system seems to insulate most of the businesses from the negative effects of estate taxation thus minimizing the aggregate costs of redistribution. Abolishing the current estate tax would generate a modest increase in wealth inequality and slightly reduce aggregate output. Decreasing progressivity of the income tax can generate large increases in output, as this stimulates entrepreneurial savings and capital formation, but at the cost of large increases in wealth concentration.
\end{abstract}

*Marco Cagetti: University of Virginia, e-mail: cacio@virginia.edu, web: http://www.people.virginia.edu/ mc6se/Research/. Mariacristina De Nardi: University of Minnesota and Federal Reserve Bank of Minneapolis, e-mail: nardi@econ.umn.edu, web: http://www.econ.umn.edu/2dcnardi. We gratefully acknowledge financial support from NSF grant (respectively) SES-0318014 and SES-0317872. De Nardi also thanks the University of Minnesota Grant-in-Aid for funding. We are grateful to Marco Bassetto and to seminar participants at many institutions for helpful comments. The views of this paper are those of the authors and not necessarily those of the Federal Reserve Bank of Minneapolis, the Federal Reserve System, or the NSF. 


\section{Introduction}

Given the well known trade-off between efficiency and redistribution, the effects of taxation on economic inequality and capital accumulation have long been a concern for economists and policy makers. Despite the relevance of this topic, there are very few papers that study this question in the context of quantitative models capable of matching the extreme concentration of wealth observed in the data. This is because constructing such a model, computing it, and calibrating it to the data is not an easy task (see Quadrini and RíosRull [32] for a discussion).

Entrepreneurship is a key determinant of investment, saving, wealth holdings and wealth inequality (see Quadrini and Ríos-Rull [33], Quadrini [30] and [31], and Gentry and Hubbard [15]). In previous work (Cagetti and De Nardi [10]) we have developed and calibrated a life-cycle model with entrepreneurial choice, and we have shown that our model reproduces very well the key features of the data. In this paper we use such a set-up to assess the long-run effects of different tax policies on entrepreneurial choices, saving, investment and wealth inequality in the U.S. economy.

We find that abolishing the estate tax generates a modest increase in wealth inequality. If everything else is held fixed, the abolition of the estate tax increases output by $1.4 \%$, but if the income tax is raised to balance the government budget constraint, the positive effect on aggregate output is reversed, and output is reduced by $0.5 \%$. This latter experiment thus generates a modest increase in wealth inequality, a drop in aggregate output, and redistribution from most of the households to the richest ones.

We also find that increasing the estate tax rate is an effective instrument to reduce inequality and that the costs and benefits of such reduction crucially 
depend on the exemption level. Our results indicate that the current effective exemption level is high enough, and that raising it further would not decrease wealth inequality, and would be detrimental for aggregate output production. We measure the current exemption level using information on the fraction of estates that pay the tax, thereby taking into account the vast opportunities to avoid the estate tax that are present in the current system.

Our simulations also indicate that decreasing progressivity significantly stimulates entrepreneurial savings and capital formation, but at the cost of a significant increase in wealth inequality.

The key forces driving our results are linked to occupational choice, saving behavior of the workers, and investment, saving and borrowing behavior of the entrepreneurs. Overall, we find that the fraction of the population devoted to entrepreneurship does not change much as a result of the various tax policies that we consider, but that the aggregate response of output, capital formation and wealth inequality deriving from changes in saving and investment behavior can be big. We learn several general conclusions from our simulations. First, a given policy affects the households in our economy differently, depending on their wealth level, age, and degree of entrepreneurial ability. Hence, the net outcome of the policy is a complex combination that depends on the fraction of people that are affected in a particular way, and on their saving and investment elasticities as a response to the given policy change. Second, since changes in the proportional income tax that we use to balance the government budget constraint affect the majority of households, and the entrepreneurs that are most borrowing constrained in particular, even a small change in such tax can have large aggregate effects, capable of reversing the intended effects of a given reform (see the abolition of the estate tax as an example). One crucial aspect of each of the tax policies that we consider is how it affects the large 
fraction of small and middle-sized businesses, rather than the few really big ones. Lastly, general equilibrium effects, and changes in the equilibrium interest rate in particular, can have large effects, and, in some cases, reverse the sign of the effects of a reform carried out in partial equilibrium, both for the aggregates, and for wealth inequality. This is because the equilibrium interest rate represents both the return to saving for workers and the opportunity cost of investment (that is, the cost of borrowing for the entrepreneurs). In many of our experiments a raise in the equilibrium interest rate increases aggregate savings by the workers, but decreases the fraction of investment carried out by the entrepreneurs even more, and could thus lower aggregate output. A change in the interest rate can also have sizeable implications for wealth inequality. In particular, an increase in the interest rate tends to lower wealth inequality through two channels: first, it tends to raise the saving and wealth holdings of the non-entrepreneurial households, who tend to be poorer, and secondly it tends to lower investment, profits and assets holdings of the entrepreneurs who tend to be much richest, thus shrinking wealth concentration.

Our findings are based on a life-cycle model with occupational choice, in which some households have the ability to employ capital more productively than others, and potential and existing entrepreneurs face borrowing constraints because contracts are imperfectly enforceable.

Several studies have studied entrepreneurship and wealth inequality. Our framework builds on Quadrini's [31] model of wealth inequality by endogenizing the firm size distribution, the interest rate at which firms borrow and lend, the amount of borrowing as a function of the entrepreneur's collateral, and by modelling the life-cycle and the intergenerational linkages. Meh [28] uses Quadrini's framework to find out the effects of switching from progressive to proportional income taxation. 
Castañeda, Díaz-Giménez and Ríos-Rull [12] construct a model with no occupational choice, in which the earnings process is calibrated to match crosssectional features of the U.S. earnings and wealth inequality, Castañeda, DíazGiménez and Ríos-Rull [11] use this framework to study the effects of switching from a progressive to a proportional income tax system.

There is a large literature on the effects of taxation on business investment, recently reviewed by Hassett and Hubbard [19], and on the effects of taxation on inequality, such as Saez [35], who analyzed the effects of optimal progressive capital income taxation on wealth inequality in a partial equilibrium model, in which the initial distribution of wealth is exogenous. Bhattacharya [7] develops a theoretical model to study bequest taxes when borrowing is limited by costlystate verification. In our work, we study how the various effects of taxation quantitatively interact in a general equilibrium model, in which the distribution of wealth and entrepreneurial choice are related because of the presence of borrowing constraints.

\section{Empirical evidence on entrepreneurship, borrowing constraints, and wealth}

Entrepreneurship is a key determinant of investment, saving, wealth holdings and wealth inequality. We summarize here some of the key facts about entrepreneurship and its role in shaping wealth inequality ${ }^{2}$.

First, entrepreneurs are a small fraction of the population (about 10\%), but hold a large share of total wealth (about 40\%) and have a higher saving

\footnotetext{
${ }^{2}$ See Cagetti and De Nardi [10], Quadrini and Ríos-Rull [33], Quadrini [30] and [31], Budria, Díaz-Giménez, Quadrini and Ríos-Rull [34], Gentry and Hubbard [15], Buera [9], and Moskowitz and Vissing-Jørgensen [29] for more evidence on entrepreneurship.
} 


\begin{tabular}{lcccc}
\hline Top \% & 1 & 5 & 10 & 20 \\
\hline $\begin{array}{l}\text { Whole population } \\
\text { percentage of total net worth held }\end{array}$ & 30 & 54 & 67 & 81 \\
\hline $\begin{array}{l}\text { Entrepreneurs } \\
\text { percentage of households in a given percentile }\end{array}$ & 63 & 49 & 39 & 28 \\
percentage of net worth held in a given percentile & 68 & 58 & 53 & 47 \\
\hline
\end{tabular}

Table 1: First row in the top panel: percentage of total net worth held by the top percent of the wealth distribution. First and second row in the second panel: percentage of entrepreneurs in a given percentile of the wealth distribution, and share of wealth held by entrepreneurs in the same percentile of the wealth distribution.

rate than non entrepreneurs (Gentry and Hubbard [15] and Quadrini [30]). Table $1^{3}$ shows that, while the distribution of wealth is extremely concentrated in the hands of a small fraction of households, entrepreneurs constitute a large fraction of the richest households, and own a large fraction of wealth even among the richest. The households in the top $1 \%$ of the wealth distribution hold around $30 \%$ of total net worth, and those in the top $5 \%$ hold more than half of the total. More than $60 \%$ of the households in the top $1 \%$, and almost one-half of those in the top 5\%, are entrepreneurs, and they hold, respectively, $68 \%$ and $58 \%$ of the wealth held by households in those quantiles.

Second, many papers have argued that households are not free to borrow as much as they would like to enter entrepreneurship or to expand their existing

\footnotetext{
${ }^{3}$ The data come from the 1989 Survey of Consumer Finances (SCF). The results for the 1992 and 1995 waves are similar. We classify as entrepreneurs the households who declare owning a privately held business (or a share of a privately held business), that have an active management role in it, and that have invested a positive amount of wealth in such business. This is consistent with the definition of entrepreneur that we use in our model. At any rate, in our previous paper we have shown that our results do not change if we use self-declared employment status (self-employed) to identify entrepreneurs.
} 
business activity, and therefore have to partly self-finance. One's own assets thus play a crucial role in determining who becomes an entrepreneur and how large his business activity is. Intergenerational transfers are also fundamental, because they may allow some households to enter entrepreneurship, either by continuing the parents' activity or by starting a new business. Holtz-Eakin, Joulfaian, and Rosen [20] study the effects of receiving a bequest on potential and existing entrepreneurs. The households in their sample are rich. Contrary to the intuition that only the poor might face borrowing constraints, the paper shows that, even in their sample, the receipt of a bequest (and thus an increase in wealth) increases the probability of starting a business, and that existing sole-proprietors who receive a bequest not only are more likely to stay in business, but also experience a substantial increase in the enterprise's receipts. Their explanation for this finding is that entrepreneurial businesses are undercapitalized because of liquidity constraints. Evans and Jovanovic [13] estimate a structural model of self-employment and find evidence of liquidity constraints. Evans and Leighton [14] find that the probability of switching into self-employment increases with asset ownership. ${ }^{4}$ Gentry and Hubbard [15] analyze SCF data and argue that costly external financing (coupled with potentially high returns on those investments) has important implications for the saving, investment, and entry decisions of continuing and potential entrepreneurs.

Another feature of the data that is interpreted by many as evidence of borrowing constraints is that the portfolios of entrepreneurs, even the richest ones, are very undiversified: business wealth constitutes a large share of the entrepreneur's total wealth, and even the entrepreneur's own assets are often

\footnotetext{
${ }^{4}$ More recently, however, Hurst and Lusardi's [22] findings seem to indicate that this correlation is probably more important for the richest than for the poor would-be entrepreneurs.
} 
used as collateral (see Cagetti and De Nardi [10] and Moskowitz and VissingJørgensen [29]).

The evidence thus suggests that entrepreneurs face borrowing constraints and that the possibility of becoming entrepreneurs and the level of possible borrowing are related to the level of the entrepreneurs' wealth. The need to accumulate assets in the presence of such constraints may also generate high saving rates among entrepreneurs (or households planning to become entrepreneurs). These features of the data stress the importance of studying the effects of different tax policies using a model that matches wealth inequality well.

\section{The model}

\subsection{Demographics}

We adopt a life-cycle model with intergenerational altruism. To make the results quantitatively interesting, we need short time periods. To make the model computationally manageable, we have to keep the number of stages of life small. To reconcile these two necessities, we adopt a modeling device introduced by Blanchard [8], and generalized by Gertler [16] to a life-cycle setting.

Our model period is one year long. Households go through two stages of life, young and old age. A young person faces a constant probability of aging during each period $\left(1-\pi_{y}\right)$ and an old person faces a constant probability of dying during each period $\left(1-\pi_{o}\right)$. When an old person dies, his offspring enters the model, carrying the assets bequeathed to him by the parent.

Appropriately parameterized, this framework generates households for which 
the average length of the working period and the retirement period is realistic. There is a continuum of households of measure 1 .

\subsection{Preferences}

The household's flow of utility from consumption is given by: $\frac{c^{1-\sigma}}{1-\sigma}$. The households discount the future at rate $\beta$ and are perfectly altruistic toward their descendants.

\subsection{Technology}

Many firms are not controlled by a single entrepreneur and are not likely to face the same financing restrictions that we stress in our model. Therefore, as in Quadrini [31], we model two sectors of production: one populated by the entrepreneurs, and one by "non-entrepreneurial" firms. The nonentrepreneurial sector is represented by a standard Cobb-Douglas production function $F\left(K_{c}, L_{c}\right)=A K_{c}^{\alpha} L_{c}^{1-\alpha}$, where $K_{c}$ and $L_{c}$ are the total capital and labor inputs in the non-entrepreneurial sector and $A$ is a constant. In both sectors, capital depreciates at a rate $\delta$.

Each person possesses two different types of ability, which we take to be exogenous, positively correlated over time and uncorrelated with each other. Entrepreneurial ability $(\theta)$ is the capacity to invest capital more or less productively. Working ability $(y)$ is the capacity to produce income out of labor.

Workers can save (but not borrow) at a riskless, constant, rate of return. Entrepreneurs can borrow and invest capital in a technology whose return depends on their own entrepreneurial ability: those with higher ability levels have higher average and marginal returns from capital. When the entrepreneur invests some working capital $k$, production net of depreciation is $(1-\delta) k+\theta k^{\nu}$ 
and $0<\nu<1$. Entrepreneurs thus face decreasing returns from investment, as their managerial skills become gradually stretched over larger and larger projects. Hence, while entrepreneurial ability is exogenously given, the entrepreneurial rate of return from investing in capital is endogenous and is a function of the size of the project that the entrepreneur implements.

We assume that the entrepreneurs work on their own project without hiring labor and that all of the workers are hired by the non-entrepreneurial sector.

In equilibrium the prices are given by the marginal products of each factor of production and the rate of return from investing in capital in the nonentrepreneurial sector must equate the risk free rate that equates savings and investment.

\subsection{Credit market constraints}

As in Albuquerque and Hopenhayn [3], Kehoe and Levine [23], and Marcet and Marimon [27], the borrowing constraints are endogenously determined in equilibrium and stem from the assumptions that contracts are imperfectly enforceable.

Imperfect enforceability of contracts means that the creditors will not be able to force the debtors to fully repay their debts as promised, but that the debtors fully repay only if it is in their own interest to do so. Since both parties are aware of this feature and act rationally, the lender will lend to a given borrower an amount (possibly zero) that will be in the debtor's interest to repay as promised.

In particular, we assume that the entrepreneurs who borrow can either invest the money and repay their debt at the end of the period, or can run away without investing it, and be workers for one period. In the latter case, 
they retain a fraction $f$ of their working capital $k$ (which includes own assets and borrowed money) and their creditors seize the rest.

In the absence of market imperfections, the optimal level of capital is only related to technological parameters, and does not depend on initial assets. In our framework, instead, the higher the amount of own wealth invested in the business, the larger the amount that the borrower would lose in case of default, hence the lower the incentive to default, and the larger the sum that the creditor is willing to lend to the entrepreneur. Hence, the entrepreneur's assets act as collateral, but the loan is not necessarily fully collateralized.

As a result, not all potentially profitable projects receive appropriate funding. Households with little wealth can borrow little, even if they have high ability as entrepreneurs. Since the entrepreneur foregoes his potential earnings as a worker, he will choose to become an entrepreneur only if the size of the firm that he can start is big enough, that is, if he is rich enough to be able to borrow and invest a suitable amount of money in his firm.

\subsection{Government and taxation}

The government is infinitely lived. It levies taxes, pays a pension $p$ to each retiree, provides a certain level $g$ of public expenditures, and pays interest on the accumulated debt. During every period, tax revenues from income, consumption, and estate taxes are equal to government expenditures, pension payments, and interest payments on the debt. We focus on the steady states and assume that the debt level is fixed.

We model progressive taxation of total income (as in Altig and Carlstrom [5]), and we allow the tax schedules to be different for entrepreneurs and non-entrepreneurs (including workers and retirees). We adopt Gouveia 
and Strauss' functional form [18], and assume the average federal tax rate $\tau_{i}(y)$ on total income $Y$ is given by:

$$
\tau_{i}(Y)=b_{i}-b_{i}\left(s_{i} Y^{p_{i}}+1\right)^{-\frac{1}{p_{i}}}
$$

Where $i=e, w$ : entrepreneurs and workers. Gouveia and Strauss [18] have shown that this functional form is flexible enough to approximate well the effective average tax rate. As explained in the calibration section, we estimate the parameters $b_{i}, s_{i}$ and $p_{i}$ from microeconomic data, separately for entrepreneurs and non-entrepreneurs.

Total income taxes paid by each household are given by:

$$
T_{i}(Y)=\tau_{i}(Y) Y+\tau_{s} Y
$$

where $\tau_{s}$ captures state and other income taxes (other than the federal ones). The government also levies a sales tax on consumption, at a constant rate $\tau_{c}$. Estates larger than a given value $e x_{b}$ are taxed at rate $\tau_{b}$ on the amount in excess of $e x_{b}$.

\subsection{Households}

At the beginning of each period, the current ability levels are known with certainty, while next period's ones are uncertain. Each young individual starts the period with assets $a$, entrepreneurial ability $\theta$, and worker ability $y$, and chooses whether to be an entrepreneur or a worker during the current period.

An old entrepreneur can decide to keep the activity going or retire, while a retiree cannot start a new entrepreneurial activity. 


\subsubsection{The young's problem}

The young's value function is:

$$
V(a, y, \theta)=\max \left\{V_{e}(a, y, \theta), V_{w}(a, y, \theta)\right\}
$$

$V_{e}(a, y, \theta)$ is the value function of a young individual that manages an entrepreneurial activity during the current period. To invest $k$ the young entrepreneur borrows $(k-a)$ from a financial intermediary at the interest rate $\bar{r} . \bar{r}$ is the risk-free interest rate at which people can borrow and lend in this economy.

$$
V_{e}(a, y, \theta)=\max _{c, k, a^{\prime}}\left\{u(c)+\beta \pi_{y} E V\left(a^{\prime}, y^{\prime}, \theta^{\prime}\right)+\beta\left(1-\pi_{y}\right) E W\left(a^{\prime}, \theta^{\prime}\right)\right\}
$$

Subject to:

$$
\begin{gathered}
Y_{e}=\theta k^{\nu}-\delta k-\bar{r}(k-a) \\
a^{\prime}=Y_{e}-T_{e}\left(Y_{e}\right)+a-\left(1+\tau_{c}\right) c \\
u(c)+\beta \pi_{y} E V\left(a^{\prime}, y^{\prime}, \theta^{\prime}\right)+\beta\left(1-\pi_{y}\right) E W\left(a^{\prime}, \theta^{\prime}\right) \geq V_{w}(f \cdot k, y, \theta) \\
a \geq 0 \\
k \geq 0
\end{gathered}
$$

The term $Y_{e}$ represents the entrepreneur's total profits. The expected value of the value function is taken with respect to $\left(y^{\prime}, \theta^{\prime}\right)$, conditional on $(y, \theta)$. Eq. (5) determines the maximum amount that an entrepreneur with given state variables can borrow. $W\left(a^{\prime}, \theta^{\prime}\right)$ is the value function of the old entrepreneur at the beginning of the period, before deciding whether he wants to stay in business or retire. $V_{w}(a, y, \theta)$ is the value function if he chooses to be a worker 
during the current period. We have:

$$
V_{w}(a, y, \theta)=\max _{c, a^{\prime}}\left\{u(c)+\beta \pi_{y} E V\left(a^{\prime}, y^{\prime}, \theta^{\prime}\right)+\beta\left(1-\pi_{y}\right) W_{r}\left(a^{\prime}\right)\right\}
$$

subject to eq. (6) and

$$
\begin{gathered}
Y_{w}=\bar{w} y+\bar{r} a \\
a^{\prime}=(1+\bar{r}) a-T_{w}\left(Y_{w}\right)-\left(1+\tau_{c}\right) c
\end{gathered}
$$

Where $\bar{w}$ is the equilibrium wage rate.

\subsubsection{The old's problem}

Since the old entrepreneur can choose to continue the entrepreneurial activity or retire, his state variables are his current assets $a$ and his entrepreneurial ability level $\theta$. His value function is given by:

$$
W(a, \theta)=\max \left\{W_{e}(a, \theta), W_{r}(a)\right\}
$$

$W_{e}(a, \theta)$ is the value function for the old entrepreneur that stays in business. $W_{r}(a)$ is the value function of the old, retired person. Define $a_{n e t}^{\prime}=a^{\prime}-\tau_{b}$. $\max \left(0, a^{\prime}-e x_{b}\right)$.

$$
W_{e}(a, \theta)=\max _{c, k, a^{\prime}}\left\{u(c)+\beta \pi_{o} E W\left(a^{\prime}, \theta^{\prime}\right)+\beta\left(1-\pi_{o}\right) E V\left(a_{n e t}^{\prime}, y^{\prime}, \theta^{\prime}\right)\right\}
$$

subject to eq. (4), eq. (7) and

$$
u(c)+\beta \pi_{o} E W\left(a^{\prime}, \theta^{\prime}\right)+\beta\left(1-\pi_{o}\right) E V\left(a_{n e t}^{\prime}, y^{\prime}, \theta^{\prime}\right) \geq W_{r}(f \cdot k)
$$


The child of an entrepreneur is born with ability level $\left(\theta^{\prime}, y^{\prime}\right)$. The expected value of the child's value function with respect to $y^{\prime}$ is computed using the invariant distribution of $y$, while the one with respect to $\theta^{\prime}$ is conditional on the parent's $\theta$ and evolves according to the same Markov process that each person faces for $\theta$ while alive. This is justified by the assumption that the child of an entrepreneur inherits the parent's firm.

A retired person (who is not an entrepreneur) receives pensions and social security payments $(p)$ and consumes his assets. His value function is:

$$
W_{r}(a)=\max _{c, a^{\prime}}\left\{u(c)+\beta \pi_{o} E W_{r}\left(a^{\prime}\right)+\beta\left(1-\pi_{o}\right) E V\left(a_{n e t}^{\prime}, y^{\prime}, \theta^{\prime}\right)\right\}
$$

subject to eq. (6) and

$$
a^{\prime}=(1+\bar{r}) a+p-T_{w}(p+\bar{r} a)-\left(1+\tau_{c}\right) c
$$

The expected value of the child's value function is taken with respect to the invariant distribution of $y$ and $\theta$.

\subsection{Equilibrium}

Let $x=(a, y, \theta, s)$ be the state vector, where $s$ distinguishes young workers, young entrepreneurs, old entrepreneurs, and old retired. From the decision rules that solve the maximization problem and the exogenous Markov process for income and entrepreneurial ability, we can derive a transition function $M(x, \cdot)$, which provides the probability distribution of $x^{\prime}$ (the state next period) conditional on $x$. 
A stationary equilibrium is given by

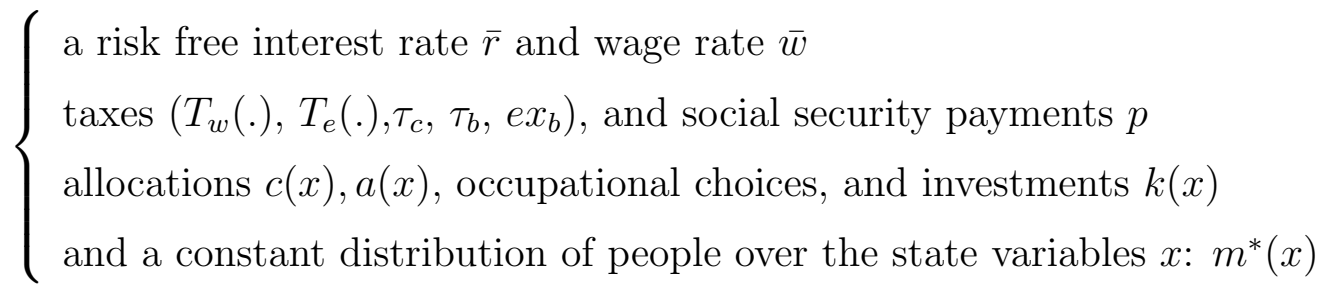

such that, given $\bar{r}, \bar{w}$ and government taxes and transfer schedules:

- the functions $c, a$ and $k$ solve the maximization problem described above.

- the capital and labor markets clear. Total labor supplied by the workers equal the total labor employed in the non-entrepreneurial sector. Total household savings in the economy equal the sum of the total capital employed in the non-entrepreneurial and entrepreneurial sectors plus government debt.

- the marginal product of labor and the marginal product of capital (net of depreciation) in the non-entrepreneurial sector are equal to $\bar{w}$ and $\bar{r}$.

- the government budget constraint balances at every period: government debt is constant and total taxes collected equal government expenditure, transfers and interest payments on government debt,

$\int\left(T_{x}\left(Y_{x}\right)+\tau_{c} c(x)+I_{o}(x) \tau_{b}\left(1-\pi_{o}\right) \cdot \max \left(0, a^{\prime}(x)-e x_{b}\right)\right) d m^{*}(x)=p \pi_{r}+g+\bar{r} D$.

The integral is over all of the population, $I_{o}$ is an indicator function that is equal to one if the person is old and zero otherwise, and $\pi_{r}$ is the fraction of retired people in the population.

- $m^{*}$ is the invariant distribution for the economy. 


\section{Calibration}

Tables 2 and 3 list the parameters of the model. Table 2 lists the parameters that we take as given and do not use to match model generated moments with moments in the data.

We take the coefficient of relative risk aversion to be 1.5 , a value close to those estimated, among others, by Attanasio et al. [6]. As standard in the business cycle literature, we choose a depreciation rate $\delta$ of $6 \%$ and the capital share in the non-entrepreneurial production function to be .33. The probability of aging and of death are such that the average length of the working life is 45 years, and the average length of the retirement period is 11 years. The logarithm of the income $y$ process for working people is assumed to follow an $\mathrm{AR}(1)$. We take its persistence to be .95, as estimated, for instance, by Storesletten et al. [38]. The variance is chosen to match the Gini coefficient for earnings of .38, the average found in the PSID. We assume that the income process and the entrepreneurial ability processes evolve independently; the exact values for the income and ability processes are described in appendix A. The social security replacement rate is $40 \%$ of average gross income (see Kotlikoff et al. [25]).

The average of the ratio between government expenditure and GDP over 1990-1999 was 18.7\% (Economic Report of the President, 2000).

As Altig at al. [4], we take the tax rate on consumption to be $11 \%$. The ratio of total indirect taxes to personal consumption expenditure in the NIPA accounts has been quite stable around 11\%-12\% from 1989 to 1999.

We pick the level of government debt (as a fraction of output) so that, given the equilibrium interest rate, every period the total interest payments on government debt equal $3 \%$ of output (as in Altig at al. [4]). 
We estimate the parameters of the tax function on total income using PSID data for 1989. See appendix B for details. Figure 1 displays our estimated average tax rates as a function of total income for the whole population, and for the subpopulations of entrepreneurs and workers.

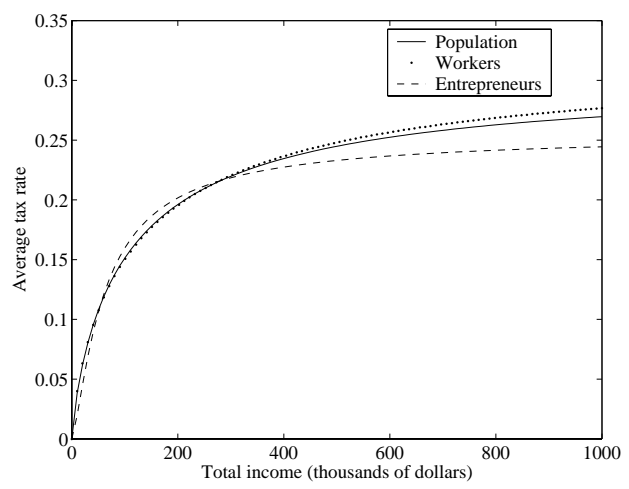

Figure 1: Estimated average tax rates for the whole population (solid line), workers (dotted line), entrepreneurs (dashed line).

Table 3 lists the remaining parameters of the model and their corresponding values in the baseline calibration. We consider only two values of entrepreneurial ability: zero (no entrepreneurial ability) and a positive number. This implies that $P_{\theta}$ is a two by two matrix. Since its rows have to sum to one, this gives us two parameters to calibrate. We also have to choose values for $\nu$, the degree of decreasing returns to scale to entrepreneurial ability, $f$, the fraction of working capital the entrepreneur can keep in case he defaults, the estate tax rate and its corresponding exemption level.

In total, these are 8 parameters to be used to match 8 moments of the data. We use the first six to pin down the following moments generated by the model: the capital-output ratio, the fraction of entrepreneurs in the population, the fraction of entrepreneurs exiting entrepreneurship during each period, the fraction of workers becoming entrepreneurs during each period, the ratio 


\begin{tabular}{ccc}
\hline & Value & Source(s) \\
Parameter & 1.5 & \\
\hline Preferences, technology and demographics & Attanasio et al. [6] \\
\hline$\sigma$ & .06 & Stokey and Rebelo [37] \\
$\alpha$ & .33 & Gollin [17] \\
$A$ & 1 & normalization \\
$\pi_{y}$ & .98 & average working life: 45 years \\
$\pi_{o}$ & .91 & average retirement life: 11 years \\
\hline Labor income process and social security payments \\
\hline$y, P_{y}$ & see appendix A & Huggett [21], Lillard et al. $[26]$ \\
$p$ & $40 \%$ average yearly income & Kotlikoff et al. [25] \\
\hline Public expenditure, government debt and taxes & \\
\hline$g$ & $18.7 \%$ GDP & NIPA \\
$D$ & see text & Altig at al. $[4]$ \\
$\tau_{c}$ & $11 \%$ & Altig at al. $[4]$ \\
$b_{w}$ & .32 & our estimates \\
$b_{e}$ & .26 & our estimates \\
$s_{w}$ & .22 & our estimates \\
$p_{w}$ & .76 & our estimates \\
$p_{e}$ & 1.4 & our estimates \\
$s_{e}$ & .42 & our estimates \\
\hline
\end{tabular}

Table 2: Fixed parameters and their sources. 


\begin{tabular}{cc}
\hline Calibrated & \\
Parameter & Value \\
\hline$\beta$ & .88 \\
$\theta$ & {$[0,0.6]$} \\
$P_{\theta}$ & see text \\
$\nu$ & .88 \\
$f$ & $75 \%$ \\
$\tau_{b}$ & $16 \%$ \\
$e x_{b}$ & 155 \\
\hline
\end{tabular}

Table 3: Calibrated parameters.

of median net worth of entrepreneurs to that of workers, and the fraction of people with zero wealth.

We choose the other two to match the revenue from estate and gift taxes ( $0.3 \%$ of output) and the fraction of the estates that pay estate taxes $(1.5 \%)$. Our effective tax rate on estates turns out to be $16 \%$, which is much smaller than the statutory tax rate (of the order of 40\%-60\%). Our exemption level turns out to be 150 times the average labor income for the workers (about 5 million dollars), compared with $\$ 650,000$ in the tax schedule (see Gale et al. [1] for a description of the statutory estate tax rates). In practice there are many ways to avoid or reduce the burden of estate taxation (see Aaron and Munnell [2] and Kopczuk et al. [24]), and thus have a much higher effective exemption level and a much lower effective marginal tax rate.

\section{Results}

Even though we do not calibrate our model to match the observed distribution of wealth, our framework with entrepreneurial choice produces a very 


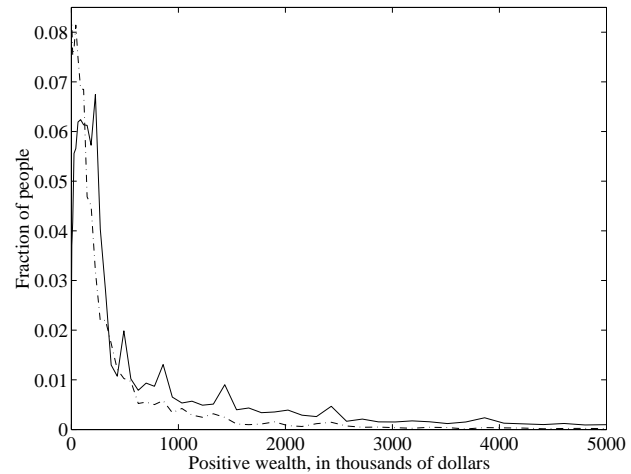

Figure 2: Distribution of wealth for the whole population. Dashdot line: data; solid line: baseline model.

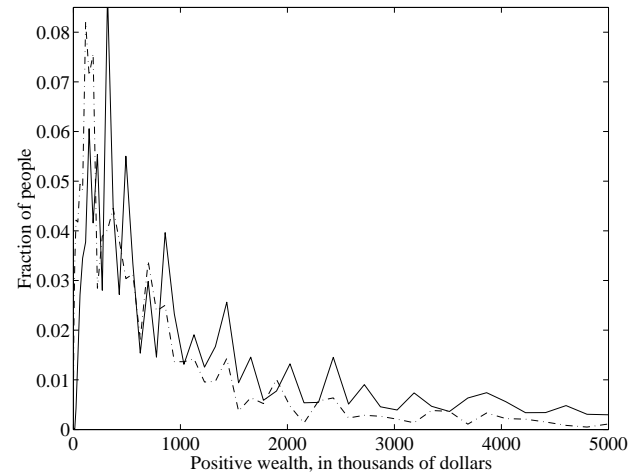

Figure 3: Distribution of the entrepreneurs' wealth. Dash-dot line: data; solid line: baseline model.

\begin{tabular}{cccccccc}
\hline $\begin{array}{c}\text { Capital- } \\
\text { output } \\
\text { ratio }\end{array}$ & $\begin{array}{c}\text { Wealth } \\
\text { Gini }\end{array}$ & $\begin{array}{c}\text { Perc. } \\
\text { entr. }\end{array}$ & $1 \%$ & $5 \%$ & $20 \%$ & $40 \%$ & $\begin{array}{c}\text { Perc. } \\
\text { at zero }\end{array}$ \\
\hline $\begin{array}{c}\text { U.S. data } \\
3.0\end{array}$ & .78 & $10-11.5 \%$ & 30 & 54 & 81 & 95 & $14 \%$ \\
\hline $\begin{array}{c}\text { Model } \\
3.0\end{array}$ & .82 & $10.5 \%$ & 30 & 61 & 86 & 95 & $14 \%$ \\
\hline
\end{tabular}

Table 4: Baseline calibration.

impressive fit of the observed wealth distribution, both for the wealth holdings of the whole population, and for those of the entrepreneurs (see Cagetti and De Nardi [10] for more discussion on the fit of the model and the role of entrepreneurship in shaping wealth concentration). To illustrate this feature, table 4 compares some data for the U.S. economy and for the model-generated data and figures 2 and 3 compare the wealth distribution, in the data and in the model, respectively for the whole population and for the population of entrepreneurs. 


\section{$5.1 \quad$ Policy experiments}

The next tables report the relevant statistics generated by the benchmark calibration for our model economy, and the corresponding numbers for the steady states of various policy experiments.

The proportional income tax rate $\left(\tau_{s}\right)$ is used as a residual to balance the government budget constraint. When we change a given tax instrument to study the effects of a policy experiment, $\tau_{s}$ will typically change, and the interest rate and the wage will adjust to clear the markets for labor and capital. To disentangle these effects we report, in some cases, three different types of experiments for a given tax policy. In the first type of experiments we keep prices and $\tau_{s}$ fixed, that is, we change the relevant tax for the given policy experiment, but keep the interest rate, the wage, and all other tax rates constant, thus allowing the government budget to become unbalanced. This experiment highlights the effect on savings and capital accumulation of the tax change per se. In the second type of experiments we still keep the interest rate and the wage constant, but let $\tau_{s}$ vary in order to balance the government budget constraint, as if the U.S. were a small open economy, or faced a linear technology. ${ }^{5}$ In the third type of experiments the interest rate and the wage adjust to clear the markets for capital and labor.

Since our model does not incorporate the choice of hours worked, ${ }^{6}$ our experiments focus on the effects of the tax on occupational choice and on savings (and thus on business formation).

\footnotetext{
${ }^{5}$ We consider steady states in which public expenditures and outstanding debt are constant as a fraction of output, so the actual amount of expenditures varies across experiments: if output decreases, so do public expenditures.

${ }^{6}$ Several works have used dynamic life-cycle models to study the labor supply responses to taxes (for instance, Altig et al. [4]). These models, however, ignore entrepreneurs.
} 
To measure the long-run ${ }^{7}$ redistributional costs and benefits of the various policy experiments we compute the fraction of yearly consumption that should be given to each household in the steady state of a given policy experiment to make the household as well off as in steady state of the benchmark economy. Positive numbers mean that a household loses from moving from the benchmark economy to the new one, viceversa for negative numbers. All of the graphs about the long-run welfare costs for the young refer to households with median labor earnings ability. In all experiments we find very little variation in the welfare costs for the young depending on their labor earnings ability.

\subsection{Abolishing the estate tax}

Rows two, three and four of table 5 study the effects of abolishing estate taxation, first for fixed prices and other taxes, and then letting taxes balance the government budget constraint for given prices, and finally allowing prices to adjust.

Given prices and other taxes, eliminating the estate tax raises aggregate output and the capital-output ratio by $1.4 \%$, and $1.3 \%$, respectively. This, however, comes at the cost of increased wealth concentration in the hands of the richest $10 \%$ of the people. While the estate tax cut does not change the total number of entrepreneurs, it does increase the size of the largest estates (net of taxes) left by the richest people, who plan to leave bequests in amounts greater than the exemption level. This mechanism tends to increase the wealth holdings of the most successful dynasties and hence increases wealth concentration.

\footnotetext{
${ }^{7}$ It would be interesting to also compute the transitions to the new steady states. Unfortunately the complexity of the code makes it unfeasible for now.
} 


\begin{tabular}{llllcllll}
\hline $\mathrm{K} / \mathrm{Y}$ & $\mathrm{Y}$ & $\begin{array}{l}\text { Perc. } \\
\text { Entr. }\end{array}$ & $\tau_{s}$ & Interest & \multicolumn{3}{c}{ Wealth held by top } \\
& & rate & $1 \%$ & $5 \%$ & $10 \%$ & $20 \%$ \\
\hline
\end{tabular}

Benchmark: $16 \%$ estate tax above exemption level

\begin{tabular}{lllllllll}
3.00 & 3.52 & 10.44 & $2.22 \%$ & $5.92 \%$ & 30.4 & 61.1 & 74.8 & 86.1 \\
\hline
\end{tabular}

No estate tax, fixed prices and other taxes

\begin{tabular}{lllllllll}
3.04 & 3.57 & 10.45 & $2.22 \%$ & $5.92 \%$ & 31.2 & 61.8 & 75.3 & 86.4 \\
\hline
\end{tabular}

No estate tax, fixed prices, endogenous $\tau_{s}$

\begin{tabular}{lllllllll}
3.02 & 3.50 & 10.40 & $2.60 \%$ & $5.92 \%$ & 31.1 & 61.7 & 75.2 & 86.2 \\
\hline
\end{tabular}

No estate tax, endogenous prices and $\tau_{s}$

\begin{tabular}{lllllllll}
3.01 & 3.48 & 10.36 & $2.60 \%$ & $5.90 \%$ & 31.4 & 62.0 & 75.3 & 86.2 \\
\hline
\end{tabular}

Table 5: Abolishing the estate tax.

A lower estate tax generates a fall in government revenues. To balance the government budget constraint, the proportional part of the income tax increases from $2.2 \%$ to $2.6 \%$. This change affects all of the households in the economy and, in particular, decreases the return (net of taxes) from investing in capital for the entrepreneurs. The entrepreneurs hit more harshly by this tax increase are most of the young ones (for which the expected time of death is still far in the future and thus the benefits from the elimination of the estate tax are small), and the old ones that are not rich enough to really benefit from the abolition of the estate tax. The reduced investment from all of these small and middle-sized entrepreneurs is large enough to reverse the gain in output, which is now half of a percentage smaller than in the benchmark case. The fraction of entrepreneurs also decreases slightly. Similar results are obtained 
when we endogenize the interest rate as the general equilibrium effects are realtively small for this policy experiment.

Figures 4 and 5 show the long-run welfare costs and benefits of living in an economy with no estate taxation (with endogenous prices and $\tau_{s}$ ) for various households, with positive numbers being losses. The graphs show that the abolition of the estate tax redistributes from the young to the old and from the poor to the rich. The young have to hold about twenty million dollars to benefit from the new system, and even for the richest young the benefit from moving to an economy with no estate tax is small, of the order of less than $1 \%$ of yearly consumption. The benefits for the old start kicking in for households with more than eight to ten million dollars (depending on the entrepreneurial ability level) and flatten out to about $6 \%$ of yearly consumption for the richest.

We thus find that eliminating the estate tax would have small negative affects on aggregate capital accumulation, would slightly increase wealth inequality, and would redistribute from the young to the old and from the majority of poor people to a very small number of rich people.

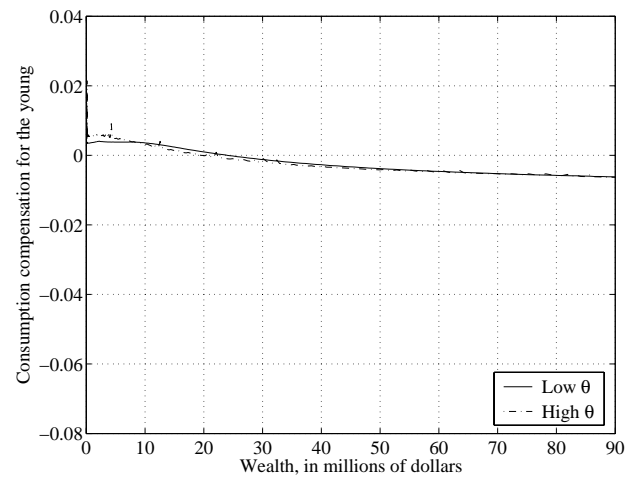

Figure 4: Consumption compensation to make the young in the economy with no estate taxes as well off as in the benchmark.

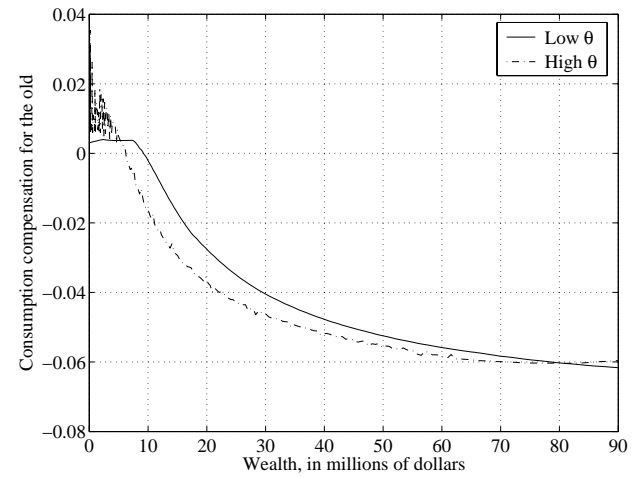

Figure 5: Consumption compensation to make the old in the economy with no estate taxes as well off as in the benchmark. 
Castañeda, Díaz-Giménez and Ríos-Rull [12] analyze the effects of a similar reform in a model with no entrepreneurial choice, in which the key force driving wealth inequality is that the rich are subject to very large idiosyncratic earnings shocks (which are calibrated to match inequality in wealth holdings). As in our model, the abolition of the estate tax in their model economy generates only a small increase in wealth inequality. Contrary to us, they also obtain a small raise in aggregate output as a result of the reform. The key additional channel at work in our framework is, as we discussed, the disincentive effect on entrepreneurial investment, which is very reactive to changes to return from entrepreneurial activity net of taxes, which is lower the higher the proportional income tax.

\subsection{Increasing the effective estate tax rate}

The second row of table 6 shows the effects of increasing the tax rate on estates from the $16 \%$ to $60 \%$, a value close to the statutory tax rate, while keeping the exemption level fixed. This experiment can be interpreted as a better enforcement of the existing estate tax system.

To study the steady state effects of this policy, we first keep all prices and taxes fixed at the same level as in the benchmark economy. Raising the estate tax for the rich reduces the size of the estates that are left to their descendants, and thus decreases wealth concentration in the upper tail. The amount of net worth held by the richest $1 \%$ and $5 \%$ decreases, respectively, from $30.3 \%$ to $27.9 \%$ and from $61.1 \%$ to $58.9 \%$. This reduction, however, comes at steep cost: a $3.7 \%$ decrease in output and $3.3 \%$ decrease in the capital-output ratio.

Rows three and four of table 6 respectively show the effects of such a policy when we allow the government budget constraint to balance (thus reducing the 


\begin{tabular}{llllcllll}
\hline $\mathrm{K} / \mathrm{Y}$ & $\mathrm{Y}$ & $\begin{array}{l}\text { Perc. } \\
\text { Entr. }\end{array}$ & $\tau_{s}$ & $\begin{array}{c}\text { Interest } \\
\text { rate }\end{array}$ & \multicolumn{4}{c}{ Wealth held by top } \\
& & & $5 \%$ & $10 \%$ & $20 \%$ \\
\hline
\end{tabular}

Benchmark: $16 \%$ estate tax above exemption level

\begin{tabular}{lllllllll}
3.00 & 3.52 & 10.44 & $2.22 \%$ & $5.92 \%$ & 30.4 & 61.1 & 74.8 & 86.1 \\
\hline
\end{tabular}

$60 \%$ estate tax above exemption level, fixed prices and other taxes

$\begin{array}{lllllllll}2.90 & 3.39 & 10.43 & 2.22 \% & 5.92 \% & 27.9 & 58.9 & 73.3 & 85.2\end{array}$

$60 \%$ estate tax above exemption level, fixed prices, endogenous $\tau_{s}$ $\begin{array}{lllllllll}2.97 & 3.63 & 10.60 & 0.90 \% & 5.92 \% & 28.3 & 59.4 & 73.8 & 85.7\end{array}$

$60 \%$ estate tax above exemption level, endogenous prices and $\tau_{s}$ \begin{tabular}{lllllllll}
2.95 & 3.47 & 10.69 & $1.71 \%$ & $6.37 \%$ & 26.4 & 57.2 & 72.1 & 84.5 \\
\hline
\end{tabular}

Table 6: Higher effective estate tax rate.

equilibrium income tax), and then for that and also for prices to equal marginal products (thus increasing the interest rate). In row 3, higher revenues from the estate tax imply a lower equilibrium income tax $\left(\tau_{s}\right.$ decreases from $2.2 \%$ to $0.9 \%)$, which in turn increases savings and total output. Output is now higher than in the benchmark case because the increased investment of those that benefit from the tax cut is large enough to make up for the fall of investment of the richest few that face the higher estate tax rate. As a result of this tax cut, more households find it profitable to enter entrepreneurship, and the number of entrepreneurs also increases (from $10.44 \%$ to $10.6 \%$ of all households).

Row four allows for the prices to adjust, in this case the general equilibrium effects are large enough to reverse the effects of the reform on the aggregates. The equilibrium interest is higher: $6.4 \%$ compared to $5.9 \%$. A higher interest 
rate tends to increase the number of entrepreneurs because workers that have high ability as entrepreneurs are now saving at a higher return and can thus enter entrepreneurship more quickly. At the same time a higher interest rate makes it more costly for the entrepreneurs to borrow and thus reduces their return from investing. Since there are decreasing returns to the entrepreneurial technology, this effect is particularly strong for the richer entrepreneurs. A higher equilibrium interest rate thus reduces the saving rate of the richest entrepreneurs, hence decreasing wealth concentration. The decrease in wealth concentration, in turn, decreases the revenues from the estate tax and thus requires a higher income tax to balance the government's budget constraint. In general equilibrium, the reduction in wealth concentration (the richest $1 \%$ now hold $26 \%$ rather than $30 \%$ of total net worth) thus comes at a non-trivial cost: aggregate output is $1.4 \%$ lower and the capital-output ratio drops by $1.7 \%$.

Hence, while increasing the estate tax rate above the existing exemption level tends to reduce wealth inequality, not only the size, but even the sign of its aggregate effects depend of how much prices respond to the reform.

The reduction of inequality obviously comes at a cost for the very richest. Figures 6 and 7 show the long-run welfare cost for various households. First notice that, as in the previous welfare comparison, the old are much more affected by increases in the estate tax than the young (for which the expected time of death is much farther in the future): for the richest old the welfare cost of moving to a higher estate taxation economy are of the order of $30 \%$ of yearly consumption, while for the richest young these welfare costs are of the order of $3 \%$. Second, the poorest are better off because of the reduction of the income tax and the increase in the interest rate, while the richest are worse off because they are those most affected by the increase of the estate tax. The 
gains of the poorest are much smaller than the losses of the richest. However, the richest are a very small fraction of the population.

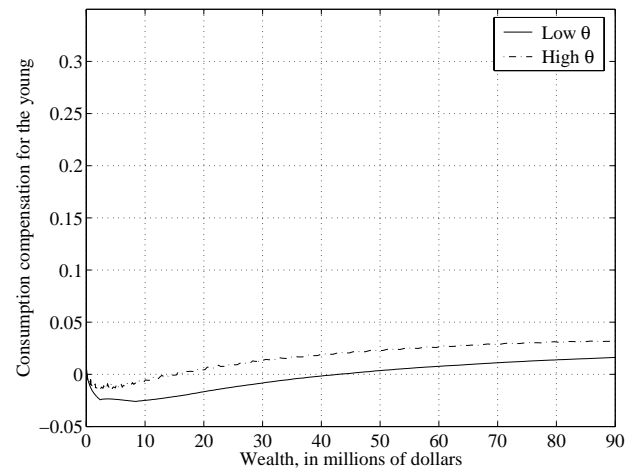

Figure 6: Consumption compensation to make the young in the high estate tax rate regime $\left(\tau_{b}=60 \%\right.$ above exemption level) as well off as in the benchmark.

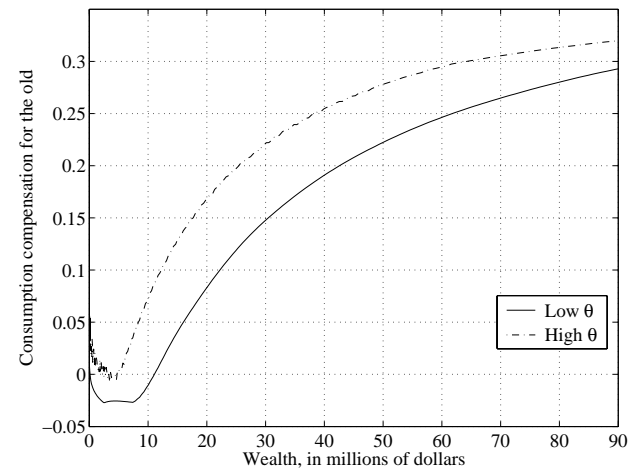

Figure 7: Consumption compensation to make the old in the high estate tax rate regime $\left(\tau_{b}=60 \%\right.$ above exemption level) as well off as in the benchmark.

\subsection{Changing the exemption level}

We now study the effects of changing the effective exemption level, while keeping the effective estate tax rate at $16 \%$. The first experiment drives the exemption level to zero. As a result, all estates are taxed at the $16 \%$. This reform changes wealth inequality very little, but has detrimental effects on aggregate output and on the capital-output ratio, which are, respectively, $2.8 \%$ and $1.0 \%$ lower than in the benchmark economy. If everything else were kept equal, this reform would increase wealth concentration as it represents a switch from progressive to proportional estate taxation. When prices adjust, however, the interest rate, which is the return from saving for the workers, and the cost of borrowing for the entrepreneurs, rises. This increase reduces entrepreneurial 


\begin{tabular}{llllcllll}
\hline $\mathrm{K} / \mathrm{Y}$ & $\mathrm{Y}$ & Perc. & $\tau_{s}$ & Interest & \multicolumn{3}{c}{ Wealth held by top } \\
& & Entr. & & rate & $1 \%$ & $5 \%$ & $10 \%$ & $20 \%$ \\
\hline
\end{tabular}

Benchmark: $16 \%$ estate tax above exemption level

$\begin{array}{lllllllll}3.00 & 3.52 & 10.44 & 2.22 \% & 5.92 \% & 30.4 & 61.1 & 74.8 & 86.1\end{array}$

$16 \%$ estate tax, zero exemption level, endogenous prices and $\tau_{s}$

$\begin{array}{lllllllll}2.97 & 3.42 & 10.47 & 1.52 \% & 6.24 \% & 30.5 & 60.7 & 74.4 & 85.6\end{array}$

$16 \%$ estate tax, higher exemption level (180), endogenous prices and $\tau_{s}$ $\begin{array}{lllllllll}3.00 & 3.46 & 10.43 & 2.44 \% & 6.05 \% & 30.0 & 60.7 & 74.5 & 85.8\end{array}$

Table 7: Changing the exemption level.

investment and thus reduces aggregate output. In presence of decreasing returns to the entrepreneurial activity, a raise in the interest rate decreases the investment of the richest entrepreneurs by more than the investment of the small and middle-sized entrepreneurs and thus also reduces their earnings and wealth holdings, hence reducing wealth concentration in the hands of the richest few. Despite a lower proportional income tax, that tends to increase workers' savings and investment, aggregate output and the capital-output ratio decline due to the reduction in investment in the entrepreneurial sector. Figures 8 and 9 show the long-run welfare costs and benefits for various households. As a result of the elimination of the estate tax exemption level all of the young people are better off (as a result of the higher interest rate and wage net of income taxes), while all of the old people that previously were below the exemption level now loose, having to pay higher estate taxes. The richest old, however, benefit from the reform, having to pay the same estate taxes and less income taxes than before. 


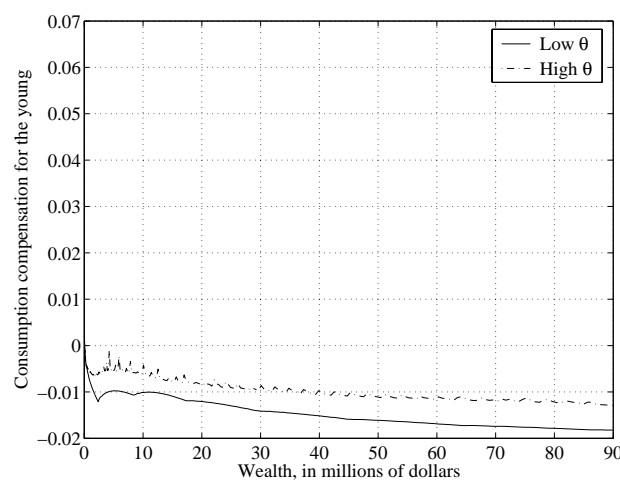

Figure 8: Consumption compensation to make the young in the no exemption estate tax rate regime $\left(\tau_{b}=16 \%, e x_{b}=0\right)$ as well off as in the benchmark.

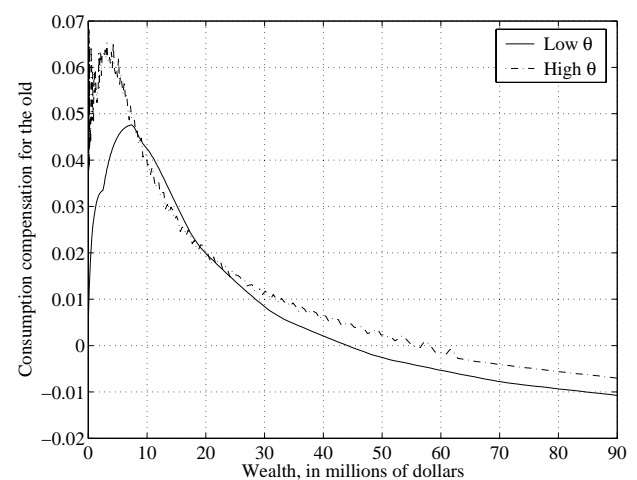

Figure 9: Consumption compensation to make the old in the no exemption estate tax rate regime $\left(\tau_{b}=16 \%, e x_{b}=0\right)$ as well off as in the benchmark.

The second experiment goes in the opposite direction, and increases the exemption level from 155 to 180 times the average labor income. As a result, the degree of wealth inequality and the capital-output ratio are basically unchanged compared to the baseline calibration, while aggregate output is $1.7 \%$ lower. A higher exemption level decreases the revenues from the estate tax, and thus requires an increase in the income tax to balance the government budget constraint, thus decreasing aggregate output. Figures 10 and 11 display the long-run welfare costs and benefits for various households for this experiment. Despite a slight increase in the equilibrium proportional income tax rate, many of the young workers are better off as a result of this reform, due the increase in the rate of return to saving. The young with high entrepreneurial ability are worse off, unless they are rich enough (around 8 million dollars): for them an increased interest rate raises the costs of borrowing more than the expected benefit from an increase in the estate-tax exemption. For the young entrepreneurs that own between 8 and 50 million dollars the reform constitutes 


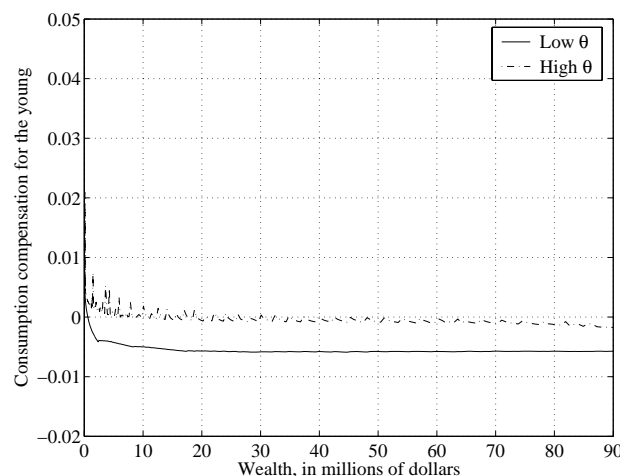

Figure 10: Consumption compensation to make the young in the higher-exemption estate tax rate regime $\left(\tau_{b}=16 \%, e x_{b}=180\right)$ as well off as in the benchmark.

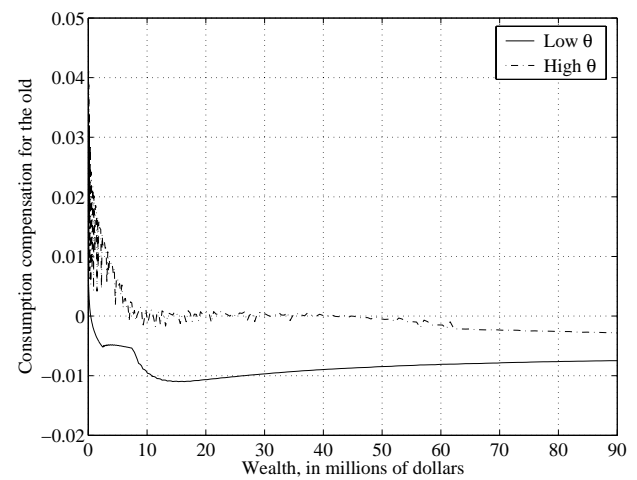

Figure 11: Consumption compensation to make the old in the higher-exemption estate tax rate regime $\left(\tau_{b}=16 \%, e x_{b}=180\right)$ as well off as in the benchmark.

a wash, while for those that are richer, the benefits outweigh the costs of the reform. The costs and benefits for the old are larger in magnitude than for the young, but follow a similar pattern: the low ability old are better off because of the higher interest rate, while the high ability one, that are entrepreneurs, trade off the cost of a higher borrowing rate with the expected benefit of a lower estate tax burden.

Looking at the overall results of the effects of changing the effective exemption level (while keeping the estate tax fixed at 16\%), we notice that wealth inequality is roughly unchanged, while the effect on aggregate output is nonmonotonic. Aggregate output is lowest (3.42) at a zero exemption level, raises to 3.52 at the effective exemption level in our current benchmark (which is about 5 million dollars), and then falls at an intermediate level between the two (2.46) when the exemption level is raised further to about six million dollars. Moving from an exemption of zero to a relatively high one, such as five million dollars, insulates most of the businesses from the negative effects of es- 
tate taxation, but increasing it further does not increase investment from very large business owners that much, while it discourages the savings and investments of all of the other household that have to pay the higher proportional income tax that is necessary to balance the government budget in presence of a smaller revenue from estate taxes. As one could intuitively think, there should be an estate-tax exemption level, possibly a high one, that allows to redistribute while keeping the aggregate costs of such redistribution low (it's a delicate trade-off between the number of people and the elasticity of their responses to tax changes). However, if we keep raising this exemption level, there will not be enough people paying taxes, and we would thus lose the benefits of this particular form of progressive taxation. Our results seem to indicate that, given the current effective estate tax rate, the effective exemption level that we have in the U.S. economy is currently high enough, and that raising it further would not decrease wealth inequality, and would instead be detrimental for aggregate output production.

\subsection{Income taxes}

The previous experiments have shown the importance of the changes in the proportional income tax required to balance the government budget constraint. In this section we focus on the effects of assuming income taxes with different degree of progressivity. Table 8 displays the results.

In the second row we set the income tax schedule for the entrepreneurs equal to that for the workers. Figure 1 shows that in the benchmark calibration the average tax rate for richer entrepreneurs is smaller than that for workers. This implies that richer entrepreneurs are now taxed more heavily relative to those in the lower tail of the distribution. This tax scheme leads to a decline in output 


\begin{tabular}{lllllllll}
\hline $\mathrm{K} / \mathrm{Y}$ & $\mathrm{Y}$ & Perc. & $\tau_{s}$ & Interest & \multicolumn{3}{c}{ Wealth held by top } \\
& & Entr. & & rate & $1 \%$ & $5 \%$ & $10 \%$ & $20 \%$ \\
\hline
\end{tabular}

Benchmark: $16 \%$ estate tax above exemption level

\begin{tabular}{lllllllll}
3.00 & 3.52 & 10.44 & $2.22 \%$ & $5.92 \%$ & 30.4 & 61.1 & 74.8 & 86.1 \\
\hline
\end{tabular}

Setting tax schedule for entrepreneurs equal to the workers'

\begin{tabular}{lllllllll}
2.90 & 3.23 & 10.35 & $2.05 \%$ & $6.24 \%$ & 26.5 & 56.7 & 71.4 & 83.9 \\
\hline
\end{tabular}

Increasing progressivity $(b)$

\begin{tabular}{lllllllll}
2.97 & 3.42 & 10.49 & $1.70 \%$ & $6.11 \%$ & 29.5 & 56.8 & 73.7 & 85.4 \\
\hline
\end{tabular}

Proportional taxation

\begin{tabular}{lllllllll}
3.41 & 4.93 & 9.1 & $18.55 \%$ & $4.38 \%$ & 39.6 & 75.0 & 86.3 & 97.9 \\
\hline
\end{tabular}

Table 8: Experiments with different progressivity of the income tax.

and in the capital-output ratio (by $8.2 \%$ and $3.3 \%$, respectively) as higher taxation discourages the formation of large businesses. As a consequence, it also decreases the concentration in the top quantiles of the wealth distribution. Figures 12 and 13 show the long-run welfare costs and benefits for various households. Both young and old workers benefit from this reform: their longrun welfare benefits are about $1 \%$ of yearly consumption. High-ability workers, unless they are too poor to become entrepreneurs, are hurt by this policy, and experience a welfare cost of up to $4 \%$ for the young, and up to $8 \%$ for the old. These welfare costs tend to flatten out or decrease with the wealth level as the difference in the slope of the two tax schedules also flattens out as income increases.

In the third row of the table, we increase the progressivity of the tax system 


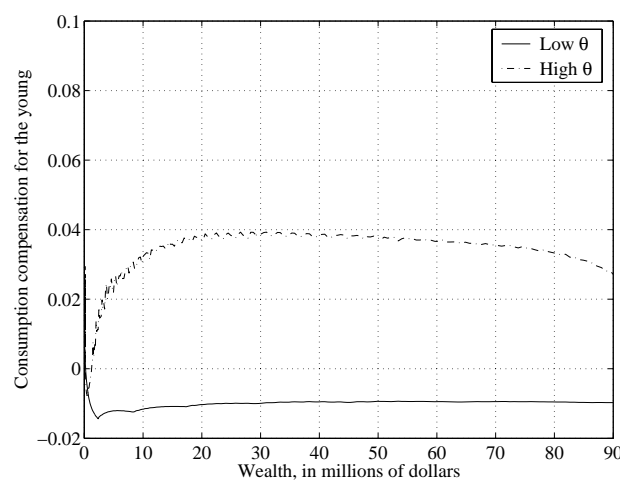

Figure 12: Consumption compensation to make the young in the same-tax-schedule-for-all economy as well off as in the benchmark.

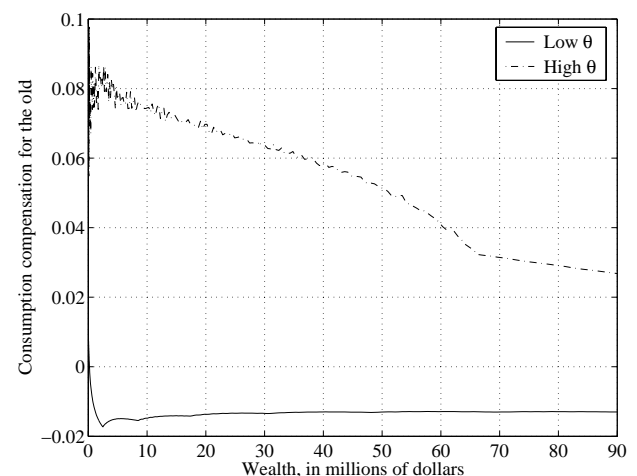

Figure 13: Consumption compensation to make the old in the same-tax-schedule-for-all economy as well off as in the benchmark.

for both entrepreneurs and workers by multiplying by 1.05 the parameter $b$ in table 9 (which implies a $5 \%$ increase in the slope of the average tax schedule). Higher progressivity hurts capital accumulation and thus decreases output, while at the same time decreasing wealth concentration. Figures 14 and 15 show the long-run welfare costs and benefits for various households. Higher progressivity hurts the welfare of both young and old entrepreneurs due to a decrease in their return net of taxes and to an increase in their cost of borrowing. In contrast, the reform benefits the workers because of the lower average tax that they have to pay, and the increase in their rate of return from saving.

Switching to proportional taxation has very large effects, both on wealth inequality and on the aggregates. This reform increases the capital-output ratio by $13.7 \%$, and aggregate output by $40 \%$, at the cost of a substantial increase in wealth concentration: the richest $1 \%$ and $20 \%$ now hold, respectively, $40 \%$ and $98 \%$ of the total net worth. Figures 16 and 17 show the long-run welfare costs 


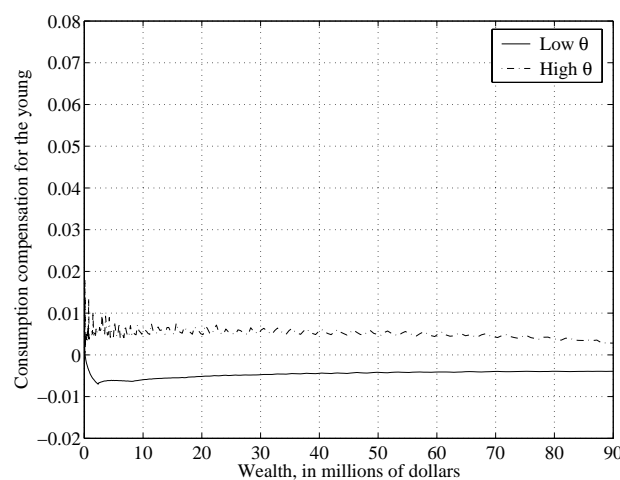

Figure 14: Consumption compensation to make the young in the more-progressive-taxation economy as well off as in the benchmark.

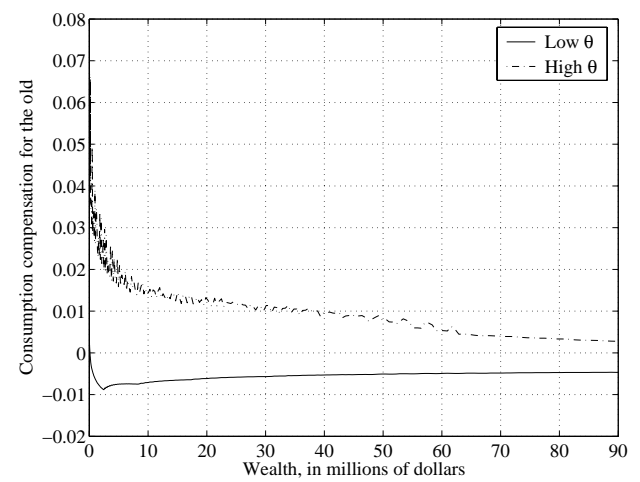

Figure 15: Consumption compensation to make the old in the moreprogressive-taxation economy as well off as in the benchmark.

and benefits for various households. Young and old workers both are worse off as a result of this reform, due to the increase in the average tax rate that they pay and to the decrease in their return to saving, depending on their wealth level, their welfare cost is of the order of $1 \%$ to $0.3 \%$ of yearly consumption. The entrepreneurs are better off, and the old more than the young ones.

Meh [28] and Castañeda, Díaz-Giménez and Ríos-Rull [11] use different models of wealth inequality to study the effects of switching from progressive to proportional income taxation. Both papers find that this reform would increase aggregate output by about $5 \%$, and raise wealth inequality, with Meh finding a smaller increase, and Castañeda, Díaz-Giménez and Ríos-Rull finding one similar to ours. In Meh's paper firm size, and hence entrepreneurial investment, is linked to an exogenous learning process, which thus limits the response of entrepreneurial investment to policy changes, while Castañeda, Díaz-Giménez and Ríos-Rull don't model the entrepreneurial channel. 


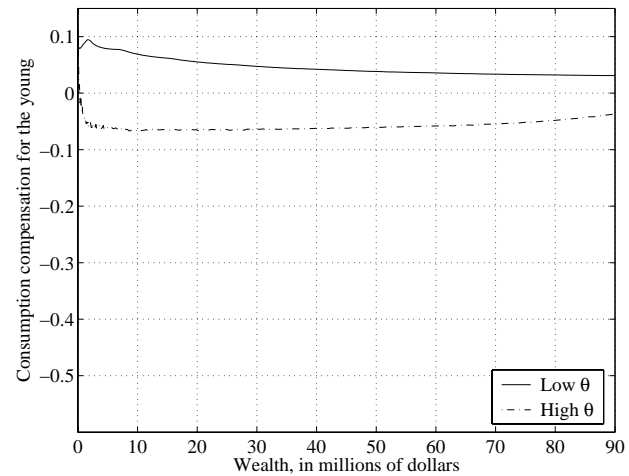

Figure 16: Consumption compensation to make the young in the proportional taxation economy as well off as in the benchmark.

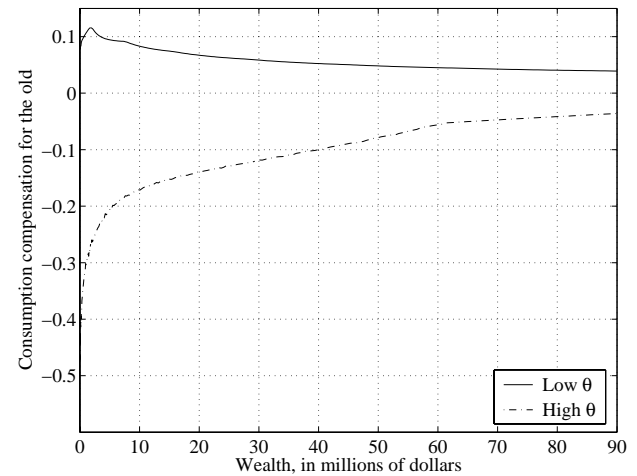

Figure 17: Consumption compensation to make the old in the proportional taxation economy as well off as in the benchmark.

\section{Conclusions}

While almost all of the tax reforms that we consider tend to have small effects on the total number of households that engage in an entrepreneurial activity, they do affect significantly the saving rate and the capital accumulation of those households who are entrepreneurs. Tax changes, therefore, can have large effects either on wealth inequality, or on aggregate capital and output, or on all of the three.

We find that abolishing the estate tax would have small effects on wealth concentration in the hands of the richest few and small, and possibly negative, effects on aggregate output. This reform would redistribute from the majority of people to the very richest.

Increasing the estate tax above the current effective exemption level would be an effective instrument to reduce wealth concentration, but would significantly hamper aggregate output and capital formation, and would imply very large long-run welfare costs for the richest few that would face the tax increase. 
Changes in the exemption level may be as important as changes in the tax rate. As few households pay the estate tax under the current system, a increase in the effective exemption level may end up hitting a much larger fraction of the population, that is affected by an increase in the proportional income tax. According to our computations, increasing the current effective exemption level would have negligible effects on inequality, and would hurt output production. On the other hand, driving the exemption level to zero would not significantly affect wealth inequality, but would reduce aggregate output. The effective estate tax system that have in place might thus be a good compromise between efficiency and redistribution.

Our computations show that, even if the estate tax generates just a small fraction of the total government revenues, it is important to take into account the change in the income tax required to reestablish budget balance in order to evaluate the effects of a given tax policy. Letting the income tax adjust can reverse the effects of an estate tax reform in some cases. While a higher estate tax tends to hurt above all the wealthy old entrepreneurs, a higher progressive income tax reduces the incentives to save throughout the wealth distribution, in particular for young entrepreneurs, who want to increase the size of their business, but face borrowing constraints.

We also find that in many reforms it is important to take into account the general equilibrium effects on prices, as, for example, an increase in the interest rate benefits the workers (who save) and tends to hurt the entrepreneurs (who borrow at that rate). For this reason, changes in prices impact both the aggregates and the distribution of wealth holdings.

We also perform various experiments pertaining to the degree of progressivity of the income tax. Decreasing progressivity can generate large increases in output, as this stimulates entrepreneurial savings and capital formation, but 
at the cost of large increases in wealth concentration.

Our model does not consider tax avoidance costs. It is possible that significant amounts of resources might be spent to decrease the tax burden, by using lawyers and accountants. The cost of tax avoidance might generate a deadweight loss that should be considered in the overall evaluation of any change in the estate tax. (See Aaron and Munnell [2] and Schmalbeck [36] for a discussion of the avoidance costs.) This is an important and to a large extent unexplored issue that we leave for future research. 


\section{References}

[1] Henry J. Aaron and William G. Gale, editors. Economic Effects of Fundamental Tax Reform. Brookings Institution Press, Washington, D.C., 1996.

[2] Henry J. Aaron and Alicia H. Munnell. Reassessing the role for wealth transfer taxes. National Tax Journal, 45(2):119-143, 1992.

[3] Rui Albuquerque and Hugo A. Hopenhayn. Optimal dynamic lending contracts with imperfect enforceability. Review of Economic Studies, 2003. Forthcoming.

[4] David Altig, Alan J. Auerbach, Laurence J. Kotlikoff, Kent A. Smetters, and Jan Walliser. Simulating fundamental tax reform in the United States. American Economic Review, 91:574-595, June 2001.

[5] David Altig and Charles Carlstrom. Marginal tax rates and income inequality in a life-cycle model. American Economic Review, 89:1197-1215, December 1999.

[6] Orazio P. Attanasio, James Banks, Costas Meghir, and Guglielmo Weber. Humps and bumps in lifetime consumption. Journal of Business and Economic Statistics, 17(1):2235, January 1999.

[7] Joydeep Bhattacharya. Credit market imperfections, income distribution, and capital accumulation. Economic Theory, 11(1):171-200, 1998.

[8] Olivier J. Blanchard. Debt, deficits, and finite horizons. Journal of Political Economy, 93(2):223-247, April 1985.

[9] Francisco Buera. A dynamic model of entrepreneurship with borrowing constraints. Mimeo, 2004.

[10] Marco Cagetti and Mariacristina De Nardi. Entrepreneurship, frictions and wealth. Federal Reserve Bank of Minneapolis Staff Report 322, September 2003.

[11] Ana Castañeda, Javier Díaz-Giménez, and José-Victor Ríos-Rull. Earnings and wealth inequality and income taxation: Quantifying the trade-offs of switching the U.S. to a proportional income tax system. Mimeo, August 1998.

[12] Ana Castañeda, Javier Díaz-Giménez, and José-Victor Ríos-Rull. Accounting for the U.S. earnings and wealth inequality. Journal of Political Economy, 111(4):818-857, August 2003.

[13] David S. Evans and Boyan Jovanovic. An estimated model of entrepreneurial choice under liquidity constraints. Journal of Political Economy, 97(4):808-827, August 1989.

[14] David S. Evans and Linda S. Leighton. Some empirical aspects of entrepreneurship. American Economic Review, 79(3):519-535, June 1989.

[15] William M. Gentry and R. Glenn Hubbard. Entrepreneurship and household savings. Mimeo, February 1999.

[16] Mark Gertler. Government debt and social security in a life-cycle economy. CarnegieRochester Conference Series on Public Policy, 50:61-110, June 1999. 
[17] Douglas Gollin. Getting income shares right. Journal of Political Economy, 110(2):458474, April 2002.

[18] Miguel Gouveia and Robert P. Strauss. Effective federal individual income tax functions: An exploratory empirical analysis. National Tax Journal, 47(2):317-339, June 1994.

[19] Kevin A. Hassett and R. Glenn Hubbard. Tax policy and business investment. In Alan J. Auerbach and Martin Feldstein, editors, Handbook of Public Economics, volume III. Elsevier, 2002.

[20] Douglas Holtz-Eakin, David Joulfaian, and Harvey S. Rosen. Sticking it out: Entrepreneurial survival and liquidity constraints. Journal of Political Economy, 102(1):53-75, February 1994.

[21] Mark Huggett. Wealth distribution in life-cycle economies. Journal of Monetary Economics, 38(3):469-494, December 1996.

[22] Erik Hurst and Annamaria Lusardi. Liquidity constraints, wealth accumulation and entrepreneurship. Journal of Political Economy, 112(2):319-347, April 2004.

[23] Timothy J. Kehoe and David K. Levine. Debt-constrained asset markets. Review of Economic Studies, 60(4):865-888, October 1993.

[24] Wojciech Kopczuk and Joel Slemrod. The impact of the estate tax on wealth accumulation and avoidance behavior. In William G. Gale and Slemrod [40], pages 299-349.

[25] Laurence J. Kotlikoff, Kent A. Smetters, and Jan Walliser. Privatizing social security in the United States: Comparing the options. Review of Economic Dynamics, 2(3):532574, July 1999.

[26] Lee A. Lillard and Robert J. Willis. Dynamic aspects of earning mobility. Econometrica, 46(5):985-1012, September 1978.

[27] Albert Marcet and Ramon Marimon. Communication, commitment and growth. Journal of Economic Theory, 58(2):219-249, December 1992.

[28] Cesaire Meh. Entrepreneurship, inequality and taxation. Working Paper, Bank of Canada, 2003.

[29] Tobias J. Moskowitz and Annette Vissing-Jørgensen. The private equity premium puzzle. Mimeo, University of Chicago, 2001.

[30] Vincenzo Quadrini. The importance of entrepreneurship for wealth concentration and mobility. Review of Income and Wealth, 45(1):1-19, March 1999.

[31] Vincenzo Quadrini. Entrepreneurship, saving, and social mobility. Review of Economic Dynamics, 3(1):1-40, January 2000.

[32] Vincenzo Quadrini and José-Victor Ríos-Rull. Models of the distribution of wealth. Mimeo, January 1997. 
[33] Vincenzo Quadrini and José-Victor Ríos-Rull. Understanding the U.S. distribution of wealth. Federal Reserve Bank of Minneapolis Quarterly Review, 21(2):22-36, spring 1997.

[34] Santiago Budria Rodriguez, Javier Díaz-Giménez, Vincenzo Quadrini, and José-Victor Ríos-Rull. Updated facts on the US distributions of earnings, income and wealth. Federal Reserve Bank of Minneapolis Quarterly Review, 26(3):2-35, 2002.

[35] Emmanuel Saez. Optimal progressive capital income taxes in the infinite horizon model. NBER Working Paper 9046, 2002.

[36] Richard Schmalbeck. Avoiding federal wealth transfer taxes. In William G. Gale and Slemrod [40], pages 113-158.

[37] Nancy L. Stokey and Sergio Rebelo. Growth effects of flat-rate taxes. Journal of Political Economy, 103(3):519-550, June 1995.

[38] Kjetil Storesletten, Chris Telmer, and Amir Yaron. Risk sharing over the life cycle: Genes or luck in the labor market. Mimeo, July 1999.

[39] George Tauchen and Robert Hussey. Quadrature-based methods for obtaining approximate solutions to nonlinear asset pricing models. Econometrica, 59(2):371-396, March 1991.

[40] James R. Hines Jr William G. Gale and Joel Slemrod, editors. Rethinking Estate and Gift Taxation. Brookings Institution Press, Washington, D.C., 2001. 


\section{A Income and entrepreneurial ability}

We assume that the income process is $\operatorname{AR}(1)$, and approximate it with a five point discrete Markov chain, using the method described in Tauchen and Hussey [39]. The gridpoints $y$ for the income process (normalized to 1 ) that we use are:

$$
\left[\begin{array}{lllll}
0.2468 & 0.4473 & 0.7654 & 1.3097 & 2.3742
\end{array}\right]
$$

and the transition matrix $P_{y}$ is:

$$
\left[\begin{array}{lllll}
0.7376 & 0.2473 & 0.0150 & 0.0002 & 0.0000 \\
0.1947 & 0.5555 & 0.2328 & 0.0169 & 0.0001 \\
0.0113 & 0.2221 & 0.5333 & 0.2221 & 0.0113 \\
0.0001 & 0.0169 & 0.2328 & 0.5555 & 0.1947 \\
0.0000 & 0.0002 & 0.0150 & 0.2473 & 0.7376
\end{array}\right]
$$

The transition matrix $P_{\theta}$ is given by:

$$
\left[\begin{array}{cc}
.97 & .03 \\
.2 & .8
\end{array}\right]
$$

\section{B Federal tax schedules}

We estimate equation (3.5) using nonlinear least squares. The data is for 1989 and is taken from Panel Study of Income Dynamics (PSID). We use the PSID dataset for this part of our analysis because it asks questions that allow us to classify households as entrepreneurs and non-entrepreneurs, and, until 1989, it also provides computed data on total taxes paid by the respondents. 


\begin{tabular}{ccc} 
Parameter & Point estimate & $95 \%$ Confidence interval \\
\hline Whole sample & & \\
$b$ & .30 & $.27-.34$ \\
$p$ & .82 & $.74-.90$ \\
$s$ & .24 & $.18-.30$ \\
\hline Workers only & & \\
$b_{w}$ & .32 & $.26-.38$ \\
$p_{w}$ & .76 & $.68-.85$ \\
$s_{w}$ & .22 & $.14-.29$ \\
\hline Entrepreneurs only & \\
$b_{e}$ & .26 & $.23-.28$ \\
$p_{e}$ & 1.40 & $1.1-1.7$ \\
$s_{e}$ & .42 & $.30-.54$ \\
\hline
\end{tabular}

Table 9: Estimates for the Federal average tax rates.

Our measure of total monetary income includes all forms of labor income, capital income, transfers, and income from entrepreneurial activities. Total federal taxes paid is the variable computed in the PSID (in our case, V18862 in the 1990 file). The dependent variable in the regression, average tax rate, is the ratio of federal taxes paid to total monetary income.

To obtain a representative sample, we exclude the poverty and Latino samples. To obtain the appropriate tax rate for our model (in which the lowest income level is positive), we also drop all observation with income smaller than $\$ 1,000$ or negative taxes paid.

To make the data on entrepreneurs consistent with the one that we use from the SCF data set and the model that we employ, we define entrepreneurs as those who declare to be self-employed and own or have a financial interest 
in a business activity and had an income of at least $\$ 1,000$ from running the business during the period. The relevant characteristics of the resulting sample of entrepreneurs has very similar characteristics of the ones from the SCF. Our estimates would be very similar if we were to assume a somewhat smaller or larger cutoff for the amount of business income received during the period.

We perform the estimation on three different samples: the whole population of households, including workers and entrepreneurs, the subpopulation of workers only and the subpopulation of entrepreneurs only. The estimated values for the three groups are shown in table 9 and plotted in figure 1 .

\section{The algorithm}

The algorithm proceeds as follows:

- Fix an interest rate $\bar{r}$ and wage rate $w$. Taking $\bar{r}$ and $w$ as given, solve for the value functions using value function iteration.

- Construct the transition matrix $M$. Compute the associated invariant distribution of wealth.

- Compute total savings and total capital invested in the two sectors implied by the invariant distribution.

- Iterate on $\tau_{s}$ until the government budget constraint is satisfied.

- Iterate on $\bar{r}$ and $w$ prices are equal to marginal productivities.

The computation of the value functions is non standard because of the presence of the endogenous borrowing constraints. For each state $x$, the en- 
dogenous borrowing constraint specifies a maximum amount $\hat{k}(x)$ that an entrepreneur can borrow. The specific function $\hat{k}$ depends however on the value functions themselves. In the algorithm we exploit the fact that, for a given set of state variables, if an entrepreneur runs away with a given level of capital $\tilde{k}$, he would also run away with any $\tilde{k}+\epsilon$, where $\epsilon \geq 0$. We adopt the following algorithm: initialize $\hat{k}(x)=k_{\max }$, the maximum investment level in the economy. We solve the value functions, iterating until convergence, conditional on this borrowing constraint. For each value of $x$, we compare the value function associated with remaining an entrepreneur and repaying the debt with the value function associated with default; we find the maximum level of investment (and borrowing) for which the entrepreneur would not default and set the new $\hat{k}(x)$ to this new value, and compute again the value functions conditional on this updated constraint. This procedure is iterated until $\hat{k}$ does not change across iterations.

As we do not constrain the $\hat{k}(x)$ functions to be decreasing when we iterate on them, we are not imposing convergence. Together with the initialization of these functions at the maximum possible level of borrowing, this implies that if the model has more than one solution, and if the algorithm converges monotonically, then we converge to the "best" solution, i.e. the one that allows for the borrowing in the economy. In all of our simulations the algorithm did converge monotonically. 